\title{
МОНГОЛ ОРНЫ ХУСНЫ ҮЙСНЭЭС БЕТУЛИН, ЛУПЕОЛ ЯЛГАСАН СУДАЛГААНЫ ДУН
}

\author{
Ч.Отгонбаяр ${ }^{I *}$, А. Чимэдцогзол ${ }^{2}$, Р.Чук \\ ${ }^{I}$ ШУА-ийн Хими, химийн технологийн хүрээлэн, Монгол улс \\ ${ }^{2}$ Идэр их сургууль, Монгол улс \\ ${ }^{3}$ Мартин-Лютерийн их сургууль, ХБНГУ \\ *Цахим шуудан: c_otgonbayar@yahoo.com
}

\section{ХУРААНГУЙ}

Хус модыг олон талын зориулалтаар ашигладаг бөгөөд тухайлбал, мод, модон бүтээгдэхүҮн, бэлэг дурсгальн зүйл үйлдвэрлэхэд өргөн хэрэглэдэг. Үүнээс гадна биологийн идэвхт нэгдлүүдийг агуулсан хус модны нахиа, шүүс, үйснээс эм, гоо сайхан болон хүнсний нэмэлт бүтээгдэхүҮн үйлдвэрлэж байна.ТҮҮнчлэн хус модноос идэвхжүүлсэн нүҮрс гарган авч, иингээгч болгон хэрэглэдэг.

Хусны үйсэнд биологийн өндөр идэвхтэй тритерпент нэгдлүүд их хэмжээтэй агуулагддаг. Иймд Монгол оронд ургадаг Хавтаг навчит хус (Betula platyphylla)-ныл үйснээс лупаны бүлэгт хамаарах бетулин, лупеольг анх удаа ялган авч, бүтэи байгууламжийг нил улаан туяаны спектрометр, $1 \mathrm{H}, 13 \mathrm{C}$ ияөийн соронзон резонансын спектроскопийн аргаар судалж тогтоов.

Түлхүүр үгс: Хавтаг навчит хус (Betula platyphylla), хусны үйс, бетулин, лупеол;

\section{ОРШИЛ}

Даяаршиж буй дэлхийн хүн ам нэмэгдэхийн хирээр хүнсний хэрэглээний соёл даган өөрчлөгдөж, хүнсний биологийн идэвхт нэмэлтүүдийг ихээр хэрэглэх болсон. Өнөө үед ургамлаас төрөл бүрийн хортой, хоргүй хавдарыг эмчлэх, исэлдэлт, нянгийн эсрэг идэвхтэй гэх мэт биологийн идэвхтэй бэлдмэл гарган авч байна.

Уламжлалт анагаах ухаанд хусны үйсийг ашиглаж үе мөч, тулай, хумхаа [10] зэрэг өвчинг эмчлэхэд өргөн хэрэглэж байсан. Хусны үйсний фитохимийн судалгаа нь эрдэмтэн судлаачдын анхаарлыг ихээр татаж, судалгааны ажил ихээр хийгдэж байна.

Манай оронд 12 зүйлийн хус ургадаг [11]. Тэдгээрийн химийн судалгаа төдийлөн хийгдээгүй.

Лупаны бүтэцтэй тритерпеноид нь ялангуяа хусны үйсэнд их хэмжээтэй хуримтлагддаг. Бетулин, лупеол нь лупаны бүтэцтэй тритерпеноид, таван цагирагаас тогтсон хэлхээтэй нэгдэл. Бетулин нь $\mathrm{C}_{30} \mathrm{H}_{50} \mathrm{O}_{2}$ гэсэн ерөнхий томьёотой, $\mathrm{C} 3, \mathrm{C} 28$ 
байрлалдаa $\mathrm{OH}$ бүлэг, лупеол нь $\mathrm{C}_{30} \mathrm{H}_{50} \mathrm{O}$ гэсэн ерөнхий химийн томъёотой, С3 байрлалдаа ОН бүлэг агуулдаг.

Гадаадын олон судлаачдын $[1,2,5,8]$ судалгаагаар эдгээр нэгдлүүд нь биологийн өндөр идэвхтэй, тухайлбал хавдарын эс Үүсэх нөхцөлийг зогсоох, өсөлтийн саатуулдаг, үрэвсэл болон вирусийн эсрэг, элэг хамгаалах зэрэг үйлчлэлтэй болох нь

\section{СУДАЛГААНЫ МАТЕРИАЛ, АРГА ЗУЙ}

Хавтаг навчит хус (Betula platyphylla)ны үйсний (газар унасан хусны үйс) дээжийг 2013 оны 8 сард Төв аймгийн Дуган хаднаас бэлдэж, судалгаанд ашигласан. Хусны зүйлийг ШУА-ын Ерөнхий ба сорилын биологийн хүрээлэнгийн (хуучин нэрээр) э/ш-ний ажилтан, доктор Д.Зоёо тодорхойлов.

Эргэх хөргөгч бүхий хоёр литрийн бөөрөнхий ёроолтой колбонд 2-3 мм-ийн өргөнтэй жижиглэсэн 200 гр хусны үйс, $10 \%$-ийн натрийн шүлтийн 650 мл уусмал, мөн 96\%-ийн 800 мл этилийн спирт хийж, 5 цагийн турш буцалгасан. Урвалын холимогийг Бюхнерийн шүүлтүүрийн тусламжтай халуунаар нь соруулж шүүв. Уусгагчийг ууршуулахад цагаан тунадас үлдсэн. Тунадасыг халуун усаар угааж саармагжуулан, шүүж хатаагаад, энэ дээжнээсээ 1 граммыг жигнэн авч, 60х6 см хэмжээтэй баганан шилэн колонкоор (силикагель 60А

\section{СУДАЛГААНЫ ҮР ДУН, ХЭЛЦЭМЖ}

Эрт дээр үеэс хусны үйс, тос, нахиа, навч зэргийг ардын уламжлалт анагаах ухаанд өргөн хэрэглэж байсан бөгөөд орчин үеийн эм, эмчилгээний бодисын найрлаганд өнөөг хүртэл өргөнөөр ашиглаж байна. Мөн хүнсний бүтээгдэхүүний найрлага, орцонд оруулж хэрэглэдэг байна $[6,12]$.

Сибирийн бүс нутагт хус мод элбэг тархаж ургадаг. Хусны үйснээс бэлэг дурсгалын зүйл, жимс, жимсгэнэ хадгалах нотлогдсон.

Иймээс өөрийн орны байгалийн түүхий эдээс төрөл бүрийн өвчнийг анагаах чадалтай биологийн идэвхт бодисуудыг ялган авч, эм бэлдмэлийн үйлчлэгч бодисын бүтэц байгууламжийг тогтоож, фармакологи, клиникийн судалгаа хийх нь зайлшгүй шаардлагатай байна.

толуол:этилацетат:н-гептан:шоргоолжны хүчил $\quad(80: 20: 10: 3)$ систем уусгагчтай хөөлгөн, 20 мл-хэмжээст шилэн саванд тус бүр тосч, бодисуудыг ялган авсан. Бодисуудын салалтыг толуол:этилацетат:нгептан:шоргоолжны $\quad$ хүчил $\quad$ (80:20:10:3) систем уусгагчтай нимгэн үеийн хроматографиар бетулин, лупеолын стандарт бодистой харьцуулан хянасан. Илрүүлэгч уусмалаар Эккерсийн урвалж ашиглав.

Ялган авсан бодисуудыг этилийн спиртэнд талсжуулах, дахин талсжуулах аргаар цэвэршүүлэв. Бүтэц байгууламжийг масс спектрофотометр, ${ }^{1} \mathrm{H},{ }^{13} \mathrm{C}$ цөмийн соронзон резонанс (Varian, Unity $400 \mathrm{MHz}$ ), нил улаан туяаны спектрометрийн (IR Prestige-21) аргаaр тус тус судлав. Хайлах температурыг температур нь үе шаттайгаар нэмэгддэг, дурантай багажаар тодорхойлов [7].

сав суулга хийхээс гадна олон төрлийн эм, эмчилгээ, гоо сайхан, хүнсний зориулалтаар хэрэглэх олон төрлийн бэлдмэл, бүтээгдэхүүн гарган авч байна.

Хуснаас бетулин ялгах олон арга байдаг. Уусгагчийн туйлт шинж чанарыг ихэсгэж, гексан, диэтилийн эфир, этилийн спирт, нэрмэл усаар зэрэг уусгагчаар Сокслетийн аппаратанд хандалж, бетулин зонхилон агуулсан гексаны хандыг баганан 
хроматографийн ялгаж судалсан [9].

ЭнэхүҮ судалгааны ажилд шүлтийн оролцоотойгоор этилийн спиртээр хандлах аргыг сонгож, зонхилох бодисоо ялгасан.

Хавтаг навчит хусны үйсэнд бетулин $25.12 \%$, лупеол $5.08 \%$-ийн агууламжтай болохыг жингийн аргаар тус тус тогтоолоо.

a) Бетулиныг пиридинд уусгаж, устөрөгчийн цөмийн соронзон резонансын спектрийг Varian, Unity $400 \mathrm{MHz}$ багаж дээр бүртгэхэд $\delta 0.78$ (д., $1 \mathrm{H}, \mathrm{J}=9.0$ Гц, Н-5), 0.81 (с.,3H, H-24), 0.84 (с.,3H, H-25), 0.85 (c.,3H, H-27), 0.97 (c.,3H, H-23), 1.01 (c.,3H, H-26), 1.21 (д.,1Н, J=1.6 Гц, Н-11b), 1.27 (д.,1H, J=1.2 Гц, Н-16b), 1.75 (с.,3Н, Н-30), 2.42 (м.,1Н, Н-19), 3.44 (дд.,1Н, J=8.0 Гц, H-3), 3.64 (c., 1H, H-28b), 3.66 (c.,1H, H-28a), 4.72 (с.,1H, Н-29a), 4.87 (с.,1H, Н-29b) сигналуудыг бүртгэсэн.

Нүүрстөрөгчийн атомын тоо, тэдгээрийн халагдалтын зэргийг тогтоох зорилгоор 13С цөмийн соронзон резонансын спектрийг бичүүлж, бүртгэсэн.

${ }^{13} \mathrm{C}$ ЦСР (100 MНz, пиридин): $\delta 149.8$ (C-20), 108.4 (C-29), 76.7 (C-3), 58.0 (C-28), 54.4 (C-5), 49.3 (C-9), 47.8 (C-18), 47.1 (C19), 46.9 (C-17), 41.6 (C-14), 39.0 (C-8), 38.1 (C-1), 37.9 (C-4), 36.2 (C-13), 36.1 (C-10), 33.5 (C-7), 33.3 (C-22), 29.0 (C-21), 28.6 (C16), 26.9 (C-2), 27.3 (C-23), 26.2 (C-15), 24.3 (C-12), 19.7 (C-11), 17.8 (C-30), 17.4 (C-6), 15.0 (C-26), 14.9 (C-25), 14.8 (C-24), 13.5 (C27).

Устөрөгч, нүүрстөрөгчийн цөмийн соронзон резонансын сигналууд нь бусад хэвлүүлэлтэй харьцуулагдсан бөгөөд сигналуудийн зөрөө \pm 3 сх-ийн дотор байв [2]. Сигнал 3.44 (дд., $1 \mathrm{H}, \mathrm{J}=8.0$ Гц) нь $3 \beta$ гидроксил тритерпений $\alpha$-д байрлах C-3ийн Н бүлгийн онцлог шинж чадвар юм.

Бетулины устөрөгчийн болон нүүрстөрөгчийн цөмийн соронзон резонансын спектрийн бичлэгийг 1, 2-р зурагт үзүүлэв.

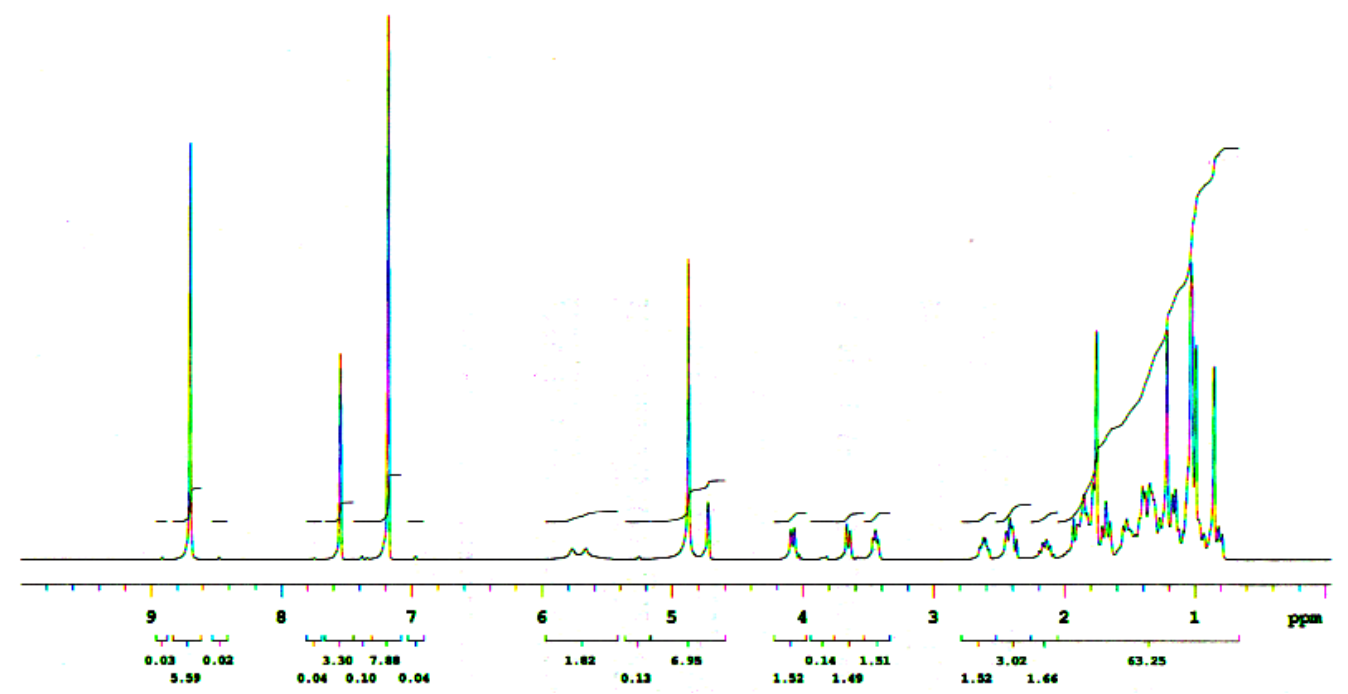

Зураг 1. Бетулины устөрөгчийн ияөмийн соронзон резонансын спектр 


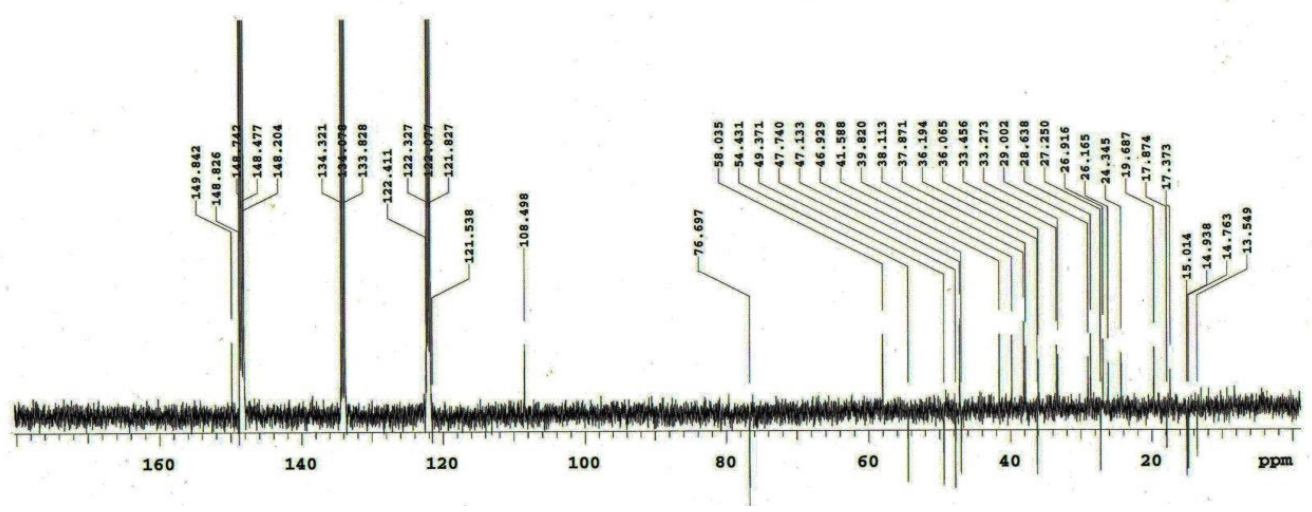

Зураг 2. Бетулины нүүрстөрөгчийн иөлийн соронзон резонанасын спектр

Бетулин, цагаан өнгөтэй, аморф нунтаг, [Lup -20(29)-ene-3ß,28-diol] C30H50O2, m/z: 442.Хайлах цэг 256-257oC.
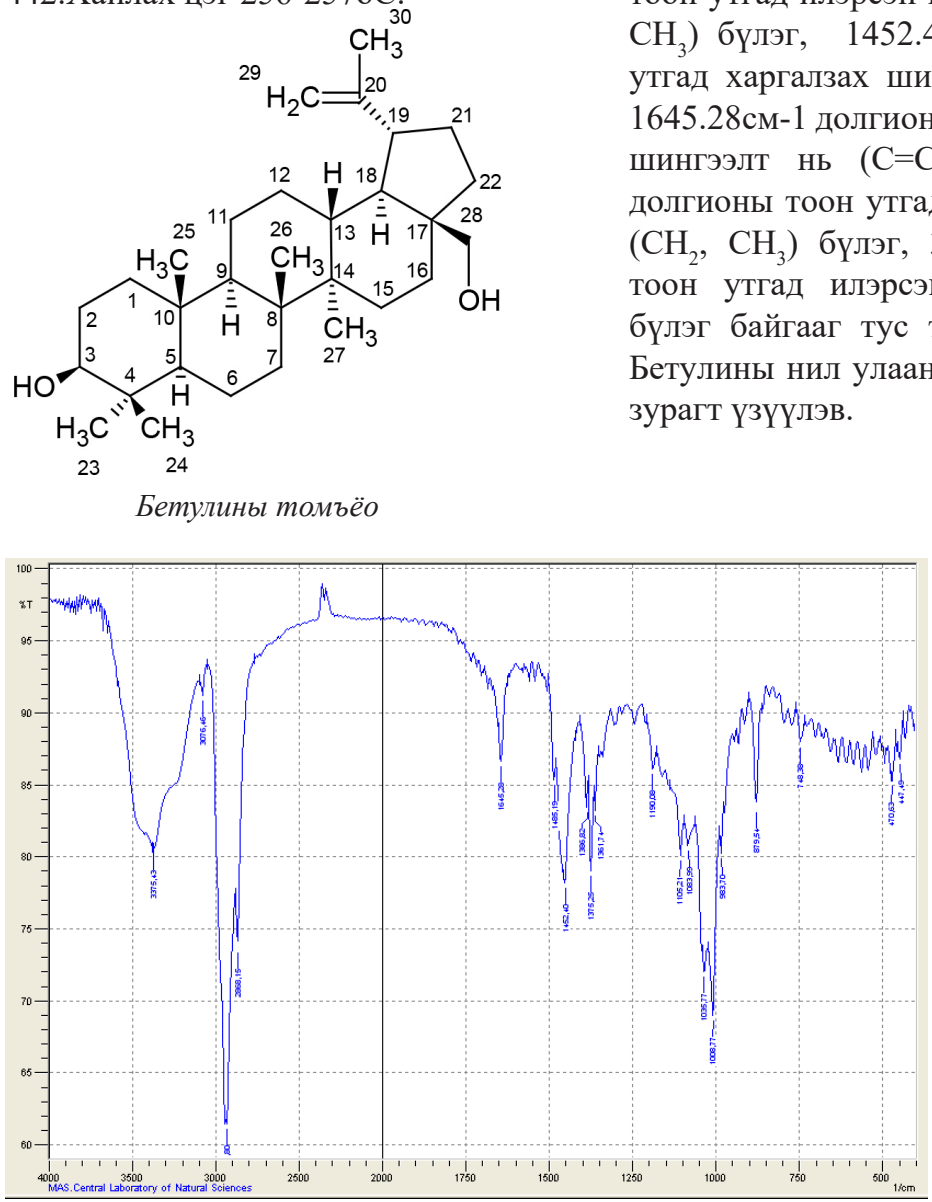

Зураг 3. Бетулины нил улаан туяаны спектр
Бетулины нил улаан туяаны спектрийн судалгаанаас үзвэл $1386.82 \mathrm{~cm}-1$ долгионы тоон утгад илэрсэн шингээлт нь $\left(\mathrm{CH}_{2}=\mathrm{CH}\right.$ $\mathrm{CH}_{3}$ ) бүлэг, $1452.40 \mathrm{~cm}-1$ долгионы тоон утгад харгалзах шингээлт нь $(\mathrm{CH})$ бүлэг, $1645.28 \mathrm{~cm}-1$ долгионы тоон утгад харгалзах шингээлт нь $(\mathrm{C}=\mathrm{C})$ бүлэг, 2868.15см-1 долгионы тоон утгад илэрсэн шингээлт нь $\left(\mathrm{CH}_{2}, \mathrm{CH}_{3}\right)$ бүлэг, $3375.43 \mathrm{~cm}-1$ долгионы тоон утгад илэрсэн шингээлт нь $(\mathrm{OH})$ бүлэг байгааг тус тус илэрхийлж байна. Бетулины нил улаан туяаны спектрийг 3-p зурагт үзүүлэв. 
б) Лупеолыг пиридинд уусгаж, устөрөгчийн цөмийн соронзон резонансын спектрийг Varian, Unity $400 \mathrm{MHz}$ багаж дээр бүртгэхэд: $\delta 0.80(1 \mathrm{H}, \mathrm{d}, \mathrm{J}=11.5 \mathrm{~Hz}$, H-5), 0.82 (3H, s, H-24), 0.88 (3H, s, H-28), 0.97 (3H, s, H-25), 1.00 (3H, s, H-27), 1.03 $(3 \mathrm{H}, \mathrm{s}, \mathrm{H}-23), 1.04(3 \mathrm{H}, \mathrm{s}, \mathrm{H}-26), 1.67(3 \mathrm{H}$, $\mathrm{s}, \mathrm{H}-30), 1.23(1 \mathrm{H}, \mathrm{m}, \mathrm{H}-22 \mathrm{a}), 1.41(1 \mathrm{H}, \mathrm{m}$, H-22b), 1.32 (1H, m, H-21a), $1.86(1 \mathrm{H}, \mathrm{m}$, H-21b), 2.47 (1H, m, H-19), 3.43 (1H, dd, $\mathrm{J}=10.0,1.0 \mathrm{~Hz}, \mathrm{H}-3), 4.72(1 \mathrm{H}, \mathrm{dd}, \mathrm{J}=4.0,1.0$ Hz, H-29a), 4.87 (1H, d, J=2.5 Hz, H-29b);

Нүүрстөрөгчийн атомын тоо, тэдгээрийн халагдалтын зэргийг тогтоох зорилгоор 13С цөмийн соронзон резонансын спектрийг бичүүлж, бүртгэсэн.

13C NMR (100 MHz, пиридин): $\delta 150.8$ (C-20), 109.6 (C-29), 77.8 (C-3), 55.6 (C-5), 50.5 (C-9), 48.3 (C-18), 48.0 (C-19), 42.9 (C17), 42.8 (C-14), 40.9 (C-22), 40.0 (C-8), 39.3 (C-13), 39.0 (C-1), 38.1 (C-4), 37.2 (C-10), 35.5 (C-16), 34.4 (C-7), 29.9 (C-21), 28.4 (C23), 28.1 (C-15), 27.5 (C-2), 25.3 (C-12), 20.9 (C-11), 19.2 (C-30), 18.5 (C-6), 17.9 (C-28), 16.2 (C-25), 16.1 (C-26), 15.9 (C-24), 14.5 (C27).

Лупеолын устөрөгч, нүүрстөрөгчийн цөмийн соронзон резонансын спектрийн бичлэгийг 4, 5-р зурагт үзүүлэв.

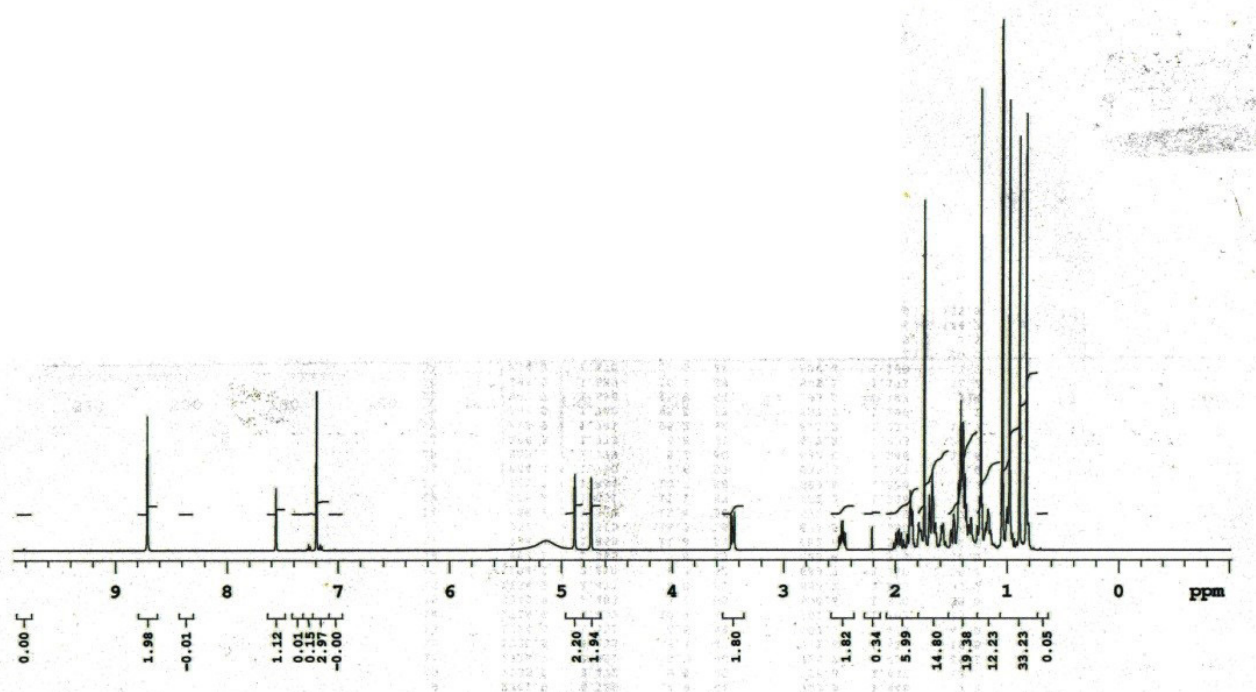

Зураг 4. Лупеольнн устөрөгчийн ияөмийн соронзон резонансын спектр

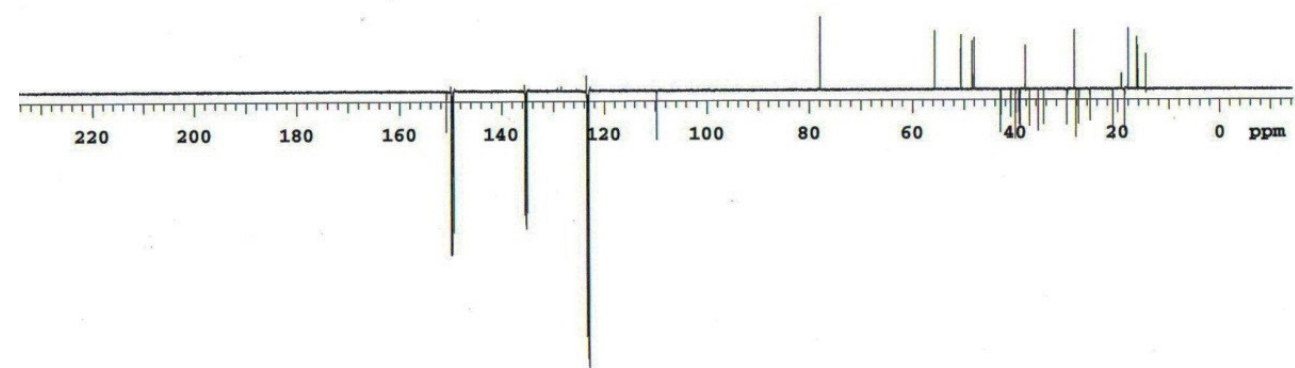

Зураг 5. Лупеолын нүүрстөрөгчийн иөөийн соронзон резонансын спектр

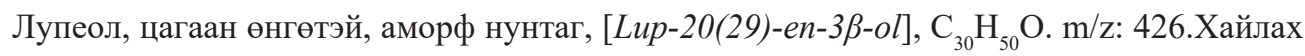
цэг $215-216^{\circ} \mathrm{C}$. 


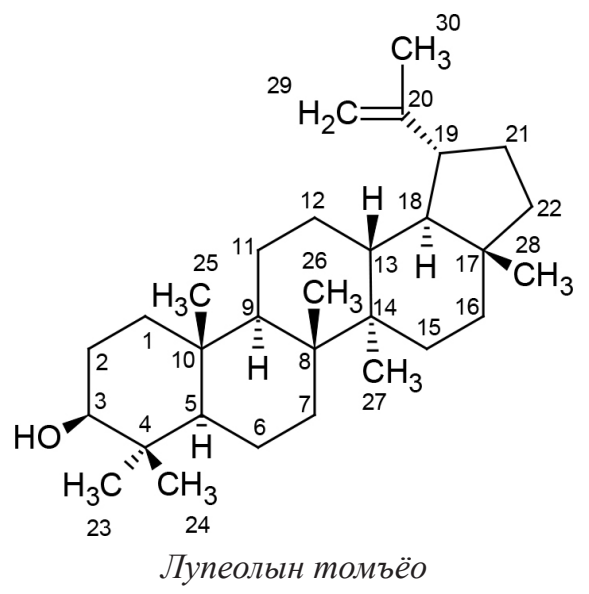

Лупеолын нил улаан туяаны спектрийн судалгаанаас үзвэл $1381.03 \mathrm{~cm}^{-1}$ долгионы тоон утгад илэрсэн шингээлт нь $\left(\mathrm{CH}_{3}\right)$ бүлэг, $1454.33 \mathrm{~cm}^{-1}$ долгионы тоон утгад харгалзах шингээлт нь (CH) бүлэг, $\quad 1639.49 \mathrm{~cm}^{-1}$ долгионы тоон утгад харгалзах шингээлт нь $(\mathrm{C}=\mathrm{C})$ бүлэг, 2872.01 $\mathrm{cm}^{-1}$ долгионы тоон утгад илэрсэн шингээлт нь $\left(\mathrm{CH}_{2}\right)$ бүлэг, $3332.99 \mathrm{~cm}^{-1}$ долгионы тоон утгад илэрсэн шингээлт нь $(\mathrm{OH})$ бүлэг байгааг тус тус илэрхийлж байна. Лупеолын нил улаан туяаны спектрийг 6-р зурагт үзүүлэв.

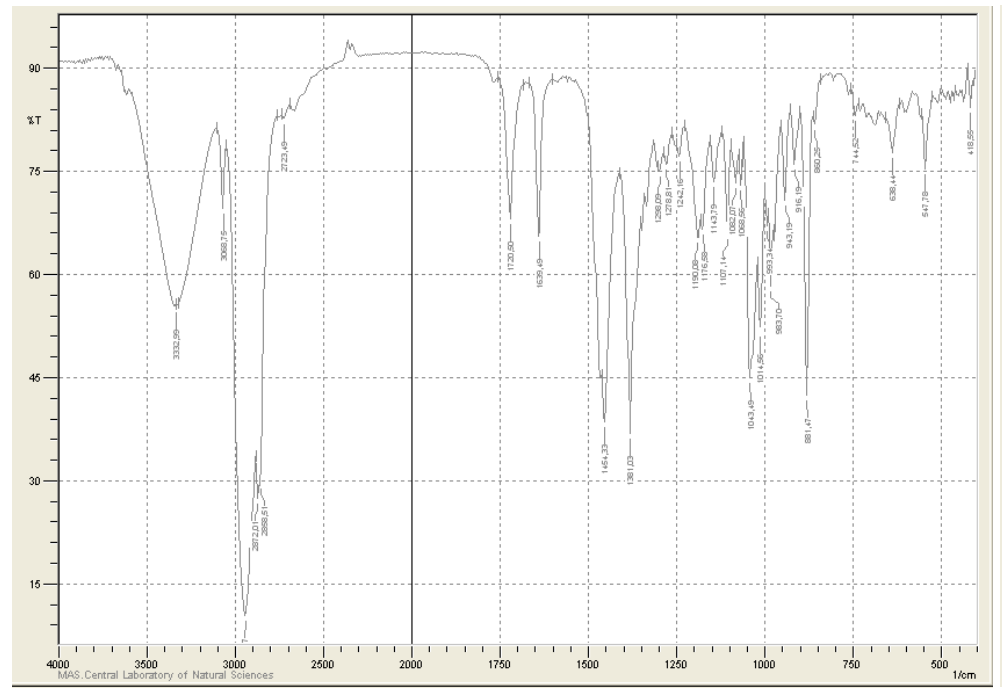

Зураг 6. Лупеольн нил улаан туяаны спектр

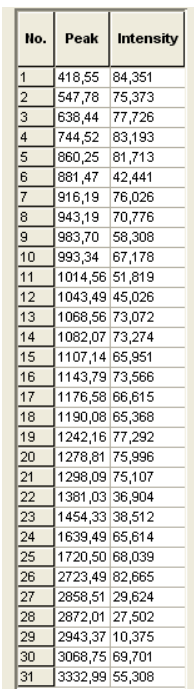

\begin{tabular}{l|lll}
30 & 3068,75 & 69,701 \\
31 & 3332,99 & 55,308
\end{tabular}
Хавтаг навчит хус (Betula platyphylla)ны үйснээс ялгасан бетулин, лупеолын бүтэц байгууламжийн судалгааны дүнг хэвлэлийн тоймтой $[3,4]$ харьцуулж, эдгээр бодисын бүтэц байгууламжийг тогтоолоо.

\section{ДУГНЭЛТ}

Монгол оронд ургадаг Хавтаг навчит хус (Betula platyphylla)-ны үйсэнд бетулин $25 \%$, лупеол $5 \%$ агуулагддаг болохыг тодорхойлов.

Хавтаг навчит хус (Betula platyphylla)ны үйснээс биологийн өндөр идэвхтэй бетулин, лупеолийг анх удаа цэврээр нь ялган авч, бүтэц байгууламжийг ${ }^{1} \mathrm{H},{ }^{13} \mathrm{C}$ цөмийн соронзон резонанс, нил улаан туяаны спектрометрийн аргаар тодорхойлж, баталгаажуулав.

Манай орны ой модны хоёрдогч түүхий эд, өөрөөр хэлбэл үйлдвэрлэлийн зориулалтаар ашиглахаар урьдчилан бэлтгэсэн, мөн байгалийн шалгарлаар унасан хус модны үйсийг боловсруулж, 
биологийн өндөр идэвхт бетулин, лупеол гарган авах бүрэн боломжтой болохыг тогтоов.

Талархал: Энэхүу судалгааны ажлыг ГЭСА, Шинжлэх ухаан технологийн сангийн SSA_023/14 дугаартай суурь судалганы төслийн санхүүжилтээр гүйцэтгэсэн бөгөөд дэмжлэг үзүүлсэн байгууллагуудад талархал илэрхийлье.

\section{НОМ ЗYЙ}

[1] Baek M.Y., Cho J.-G., Lee D.-Y. Isolation of triterpenoids from the stem bark of Albizia julibrissin and their inhibition activity on ACAT-1 and ACAT-2, J. Korean Soc. Appl. Biol. Chem., 2010. 53, 310-315.

[2] Chowwanapoonpohn S., Buddhasukh D. Isolation of Pentacyclic Triterpenoid Compounds from Lithoscarpus elegans (BL.) Hatus. Ex Soep. By Electrocoagulation. In Perspectives in Natural Product Chemistry Proc. Acta Hort. 677, ed. Baser K.H.C., Franz G., Canigueral S., et. al. International Society for Horticultural Science, 2005, Chicago 19-25.

[3] Elvira.E, Kovac-Besovic, Kemal Duric. Identification and isolation of pharmacologically active triterpenes in Betuale cortex, Betula pendula Roth., Betulaceae. Bosnian journal of basic medical sciences 2009, 9(1):31-38

[4] Ernest Wenkert, G.Vernon Baddeley, Ivor R.Burfitt and Louis N.Moreno. Carbon-13 Nuclear Magnetic Resonance Spectroscopy of Naturally-occurring Substances, Organic magnetic resonance, 1978, Vol 11, № 7 .

[5] Gallo, M.B.C., Sarachine M.J., Biological activities of lupeol. Intl. J.Biomed. Pharma. Sci., 3, 2009, 46-66.

[6] Princa P.Sharma, R.K.Roy B and Anurag, Dinesh Gupta. Pentacyclic Triterpinoids from Betula utilis and Hyptis suaveolens. International Journal of PharmTech Research. ISSN : 0974-4304, 2010, Vol.2, №2, pp 1558-1562

[7] Rene Csuk, Stefan Schwarz, Bianka Siewert, Ralph Kluge and Dieter Strohl Synthesis and Antitumor Activity of Ring A-modified Glycyrrhetinic Acid Derivatives. Z. Naturforsch. 2011, 66b, pp $521-532$.

[8] Ressmann A., Strassl K. and Gaetner P. New aspects for biomass processing with ionic liquids: towards the isolation of pharmaceutically active betulin. Green chem., 2012, doi:10.1039/C2GC16389F

[9] Ronny Sczepek, Renate Schdfer, Choijiljav Otgonbayar and Renŭ Csuk, Synthesis and cytotoxic properties of alkynictr iterpenoid Mannich compounds, Mediterranean Journal of Chemistry 2015, 4(3), 126-137

[10] Володя Ц., Монгол орны эмийн ургамльг эмнэлэгт хэрэглэх аргачлал, Улаанбаатар хот, 2014 он, 390-393.

[11] Грубов В.И., Монголын гуурст ургамал таних бичиг, УБ., 2008 он, 91-93.

[12] Лигаа У., Б.Даваасүрэн, Н.Нинжил, Монгол орны эмийн ургамльг өрнө, дорнын анагаах ухаанд хэрэглэхүй, УБ., 2005 он. 460-463. 


\title{
RESULTS OF THE STUDY ON EXTRACTION BETULIN AND LUPEOL FROM THE BIRCH OF MONGOLIA
}

\author{
Otgonbayar Ch. ${ }^{1 *}$, Chimedtsogzol A. ${ }^{2}$, R.Csuk ${ }^{3}$ \\ ${ }^{1}$ Institute of Chemistry and Chemical Technology, MAS, Mongolia \\ ${ }^{2}$ Ider university, Mongolia \\ ${ }^{3}$ Martin-Luther Universitdt Halle-Wittenberg, Germany \\ *corresponding author,e-mail: c_otgonbayar@yahoo.com
}

\begin{abstract}
Bark of the birch (Betula platyphylla), originated in Mongolia, contains $25 \%$ betulin and 5\% lupeol. High biological active betulin and lupeol are extracted purely from birchbark (Betula platyphylla) for the first time. The structure of extracted betulin and lupeol are determined and verified by $1 \mathrm{H}-\mathrm{NMR}, 13 \mathrm{C}-\mathrm{NMR}$ und IR.

It is possible to extract highly biological active betulin and lupeol from birchbark, which is the second biggest primary raw material from our country's forest. It is produced in the process of preparing birch for industrial use and furthermore many birches fall due to natural circumstances.
\end{abstract}

Keywords: Betula platyphylla, birchbark, betulin, lupeol; 